\title{
Stability Analysis in Dual Purpose Sorghum [Sorghum bicolor (L.) Moench]
}

\author{
B.L. Meena ${ }^{1}$, B. R. Ranwah $^{2}$, H. S. Meena ${ }^{1}$, M. D. Meena ${ }^{1}$, K. N. Meena ${ }^{1}$ and P. K. Rai ${ }^{1}$ \\ ${ }^{1}$ ICAR-DRMR, Bharatpur Rajasthan-321303, India \\ ${ }^{2}$ MPUAT, Rajasthan College of Agriculture, Udaipur Rajasthan -313001, India \\ *Corresponding author
}

\section{A B S T R A C T}

The present investigation was under taken for 10 lines and 3 tester using line $\mathrm{x}$ tester mating design consisted of 46 entries including 10 lines, 3

\section{Keywords}

$\mathrm{L} x \mathrm{~T}$ mating design Genotypes,

homogenous error

Article Info

Accepted:

20 February 2020

Available Online:

10 March 2020 testers, 30 hybrids and three checks viz., CSV 23, CSV 27 and CSH25. These were evaluated in RBD with three replications during kharif 2015 in four environments created by using different spacing viz., $22.5 \times 5 \mathrm{~cm}\left(\mathrm{E}_{1}\right)$, $30 \times 10 \mathrm{~cm}\left(\mathrm{E}_{2}\right), 45 \times 10 \mathrm{~cm}\left(\mathrm{E}_{3}\right)$ and $60 \times 10 \mathrm{~cm}\left(\mathrm{E}_{4}\right)$. The analysis of variance for $\mathrm{L} \times \mathrm{T}$ mating design in individual environment revealed significant differences between genotypes for most of the characters in most of the environments. The Bartllet test revealed homogenous error variance for plant height and ear head length. The pooled analysis revealed significant differences between the environments, genotypes, parents and crosses for both the characters. This indicates presence of significant variability for these characters. In 22 stable genotypes for plant height line $\mathrm{L}_{4}$ and crosses $\mathrm{L}_{2} \times \mathrm{T}_{1}$ and $\mathrm{L}_{4} \times \mathrm{T}_{2}$ having $\mathrm{b}_{\mathrm{i}}=1$ for rest of the 19 genotypes $b_{i}$ neither deviating from zero nor from unity. Similarly, for ear

\section{Introduction}

Sorghum is predominantly self-pollinated crop endowed with a wide range of genetic variability due to its wide range of adaption and free gene exchange among various races. Careful selection of parents for hybridization is a key of success in any breeding programme. Some idea about the usefulness of parents may be obtained from their per se performance, breeding for wide adaption is important aspect in genetic improvement of crop plants. It is well known that a specific genotype may not exhibit the same performance in all the environments nor all the genotypes respond alike to a specific environment.

Such differential response of genotypes to varying environmental conditions reduces the agricultural production. Therefore, knowledge about behavior of genotypes in different 
environment is essential for their recommendation and their further use in breeding programme. For this, it is desirable to see the impact of various environments on the sorghum genotypes in order to identify the parents and /or crosses for further utilization in breeding programme. Sorghum bicolor (L.) Moench $(2 \mathrm{n}=20)$, family poaceae is one of the most important crops in the world because of its adaptation to a wide range of ecological conditions, suitability for low input cultivation and diverse uses (Doggett, 1988).

Sorghum occupies fifth position after wheat, rice, maize and barley at world level, both in area and production. The crop is widely grown for food, feed, fodder, forage and fuel in the semi-arid tropics (SAT) of Asia, Africa, America and Australia. It occupies $58.20 \mathrm{~m}$ ha area in the world with an annual grain production of $68.87 \mathrm{~m}$ tones and productivity of $1535 \mathrm{~kg} / \mathrm{ha}$ (FAO, 2015). In India, it covers about $5.82 \mathrm{~m}$ ha with an annual grain production of $5.39 \mathrm{~m}$ tonnes and productivity of $926 \mathrm{~kg} / \mathrm{ha}$ (FAO, 2015).

The stability in the production is on account of availability of high yielding varieties and inputs. Maintenance of plant population in per unit area is very difficult. Buffering ability of the genotypes is the only way to cope up with the available space. Therefore, breeding for buffering ability is important aspect in genetic improvement of crop plants. Development of such a hybrid/variety, which gives a constant and desirable performance over wide range of spacing (Meena et al., 2018), is needed.

For this, it is desirable to see the impact of various spacing on the yield of sorghum genotypes and identification of genotypes having buffering ability. In view of the above facts, present investigation entitled "Stability Analysis in Dual Purpose Sorghum [Sorghum bicolor (L.) Moench]" has been planned and genotypes were evaluated during kharif, 2014 and kharif, 2015 at Instructional Farm, Rajasthan college of Agriculture, Udaipur to estimate stability of genotypes. $\mathrm{V}$

\section{Materials and Methods}

The present investigation entitled Stability Analysis in Dual Purpose Sorghum [Sorghum bicolor (L.) Moench] was conducted at Instructional farm, Rajasthan College of Agriculture, Udaipur during kharif 2014 and kharif 2015.

\section{Experimental site and condition}

Geographically Instructional Farm is situated at $24^{\circ}-35^{\prime}$ North latitude and $73^{\circ}-42^{\prime}$ East longitude. The elevation of institution farm is 582.17 meters above mean sea level. The climatic conditions of the area represent subtropical condition with humid climate. The soil of experimental fields was clay loam, deep, well drained, alluvial in origin and having fairly good moisture holding capacity (Table 3.3).

\section{Experimental material}

On the basis of days to flowering and suitability for dual purpose 36 lines were received from ICRISAT. After evaluation at this station 10 lines were identified on the basis of nicking of flowering. Three testers were identified on the basis of availability of restorer gene and past performance. Checks CSV 23, CSV 27 and CSH 25 were national checks in coordinated trials. The experimental material comprised of 10 male sterile lines viz., ICSA 29003(L $\left.\mathrm{L}_{1}\right)$, ICSA $29004\left(\mathrm{~L}_{2}\right)$, ICSA $29006\left(\mathrm{~L}_{3}\right)$, ICSA $29010\left(\mathrm{~L}_{4}\right)$, ICSA 29011(L5), ICSA $29012\left(\mathrm{~L}_{6}\right)$, ICSA 29013 $\left(\mathrm{L}_{7}\right)$, ICSA $29014\left(\mathrm{~L}_{8}\right)$, ICSA $29015\left(\mathrm{~L}_{9}\right)$ and ICSA 29016 ( $\left.\mathrm{L}_{10}\right)$, three restorer testers viz., SPV $245\left(\mathrm{~T}_{1}\right)$, SPV $1430\left(\mathrm{~T}_{2}\right)$ and SPV 1822 $\left(\mathrm{T}_{3}\right)$ and three checks viz. CSV 23, CSV 27, and CSH 25. These 10 lines and three testers 
were crossed in factorial fashion to obtain the 30 hybrids. The crossing programme was attempted at Udaipur during kharif 2014 and at Warangal during rabi 2014-15.

\section{Experimental design}

In Line $\mathrm{x}$ Tester mating design experiment total 46 genotypes (10 lines, 3 testers, 30 crosses and 3 checks) were grown in a randomized block design with three replications in four different environments during kharif 2015 at Instructional farm, Rajasthan College of Agriculture, Udaipur (Rajasthan).

Each genotype was sown in a single row plot of 2-meter length maintaining a separate crop geometry (spacing) for each environment. The row to row and plant to plant spacing was $22.5 \mathrm{~cm} \times 5 \mathrm{~cm}, 30 \mathrm{~cm} \times 10 \mathrm{~cm}, 45 \mathrm{~cm} \times 10$ $\mathrm{cm}$ and $60 \mathrm{~cm} \mathrm{x} 10 \mathrm{~cm}$ in $E_{1}, E_{2}, E_{3}$ and $E_{4}$, respectively.

\section{Traits under investigation}

Following phenological, fodder and quality traits were measured. Days to $50 \%$ flowering, plant height $(\mathrm{cm})$, ear head lngth, grain yield $\left(\mathrm{q} \mathrm{ha}{ }^{-1}\right)$, green fodder yield $\left(\mathrm{q} \mathrm{ha} \mathrm{h}^{-1}\right)$, protein content in grain $(\%)$, protein content in fodder $(\%)$, seed index and harvest index $(\%)$,

\section{Statistical analysis}

Plot means of all the characters were subjected to various statistical analysis. The statistical analysis followed for Line $\mathrm{x}$ Tester mating design experiment was as follows.

The plot means of each character were subjected to analysis of variance for individual environment as well as over the environment where error variance in different environment were homogeneous using least square technique of Fisher (1932).

\section{Analysis of variance for individual environment}

ANOVA for individual environment is presented in Table 3.7. In this table looking to the materials used the genotypic variation was further partitioned as mentioned in the table. The linear model of analysis of variance for individual environment was as under:

$$
Y_{i j}=\mu+G_{i}+R_{j}+\sigma_{i j}
$$

Where,

Yij $=$ Value of ith genotype in $\mathrm{jth}$ replication,

$\mu=$ Population mean,

$\mathrm{Gi}=$ An effect of ith genotype which were further partitioned in Parents, Checks, Crosses, Lines, Testers and Line $\mathrm{x}$ Tester

$\mathrm{Rj}=$ An effect of $\mathrm{jth}$ replication and

$\sigma \mathrm{ij}=$ An uncontrolled variation associated with ithgenotype and jth replication.

The mean, general mean, standard error, critical difference and coefficient of variation were calculated as:

$$
\begin{gathered}
\operatorname{Mean}\left(\overline{\mathrm{X}}_{\mathrm{i}}\right)=\sum_{i=1}^{r} X_{i j} / \mathrm{r} \\
\operatorname{General~Mean}(\overline{\mathrm{X}})=\sum_{i=1}^{g} \sum_{j=1}^{r} X_{i j} / \mathrm{rg}
\end{gathered}
$$

If mean square due to genotype was significant then $\mathrm{CD}$ was calculated as follow:

$\mathrm{CD}=\mathrm{SE}$ (Diff.) $\mathrm{x}_{[(\mathrm{r}-1)(\mathrm{g}-1)]}$ at $5 \%$ or $1 \%$ level of significance

$$
C V \%=\frac{\sqrt{M S E}}{\bar{X}} \times 100
$$

Where,

$$
\bar{X}_{i}=\text { mean of the } i^{\text {th }} \text { genotype }
$$


$\bar{X}=$ mean over genotypes and replications

$\bar{X}_{i j}=$ value of $i^{\text {th }}$ genotypes in $j^{\text {th }}$ replication $r, g=$ number of replications and genotypes, respectively

$$
S E(\text { Diff. })=\sqrt{\frac{2 M S E}{r}}
$$

$\mathrm{MSE}=$ Error mean square

\section{Analysis of variance over environments}

The statistical model for pooled analysis of variance was as under:

$$
Y_{i j k}=\mu+G_{i}+R_{j}+E_{k}+G_{j k}+\sigma_{i j k}
$$

Where,

Yijk $=$ Yield of the ith genotype in jth replication of kth environment,

$\mu=$ General mean,

$\mathrm{Gi}=$ An effect of ith genotype where genotypes were further partitioned into checks, parents, hybrids, parent v/s checks and parent's vs hybrids.

Parents were further partitioned between testers, lines and testers' v/s lines. Hybrids were partitioned into effects of testers (GCA tester), effects of lines (GCA line) and their interactions line $\mathrm{x}$ tester (SCA).

$\mathrm{Rj}=$ An effect of jth replication, $\mathrm{Ek}=$ An effect of kth environment,

$(\mathrm{GE}) \mathrm{ik}=\quad$ An interaction effect of ith genotype with kth environment.

This effect was further partitioned into the interaction of environment with checks, parents ( testers, lines and testers $\mathrm{v} / \mathrm{s}$ lines) parents $\mathrm{v} / \mathrm{s}$ checks, parents $\mathrm{v} / \mathrm{s}$ hybrids and hybrids ( GCA tester, GCA line and SCA)

$\square \mathrm{ijk}=A n$ uncontrolled variation associated with ith genotype in jth replication and kth environment.

\section{Bartlett's test}

Before doing the pool analysis of variance homogeneity of error variance was tested using the Bartlet test. Pool analysis was performed only when error variance was homogeneous in different environments.

Where

$$
\text { Corrected } \chi^{2}=\frac{\chi^{2}}{C F}
$$

$\chi^{2}=\left(\sum_{i=1}^{l} d f_{i}\right) \times \log e E M S P-\sum_{i=1}^{l}\left(d f_{i}, \log e E M S_{i}\right)$

$C F=1+\frac{1}{3(l-1)} \times\left[\sum_{i=1}^{l} \frac{1}{d f_{i}}-\frac{1}{\sum_{i=1}^{l} d f_{i}}\right]$

$\mathrm{df}_{\mathrm{i}}=$ Error degrees of freedom in $\mathrm{i}^{\text {th }}$ environment

$1=$ Number of environments

EMSP $=$ Pool error mean square, and

$\mathrm{EMS}_{\mathrm{i}}=$ Error mean square in $\mathrm{i}^{\text {th }}$ environment.

\section{Genotype $\mathrm{x}$ environment interactions and stability parameters}

The phenotypic stability of genotype for different characters having homogeneous error variance in different environment was estimated according to model proposed by Eberhart and Russell (1966).

The statistical model of the analysis was as follows:

$$
\mathrm{Y}_{\mathrm{ij}}=\mu_{\mathrm{i}}+\beta_{\mathrm{i}} \mathrm{I}_{\mathrm{j}}+\delta_{\mathrm{ij}}
$$

Where,

$Y_{i j}=$ Mean performance of $i^{\text {th }}$ genotype in $j^{\text {th }}$ environment

$\mu_{\mathrm{i}}=$ Mean of $\mathrm{i}^{\text {th }}$ genotype over the environments

$\beta_{\mathrm{i}}=$ The regression coefficient of $i^{\text {th }}$ genotype

$\delta_{\mathrm{ij}}=$ Deviation from regression of the $\mathrm{i}^{\text {th }}$ genotype in $\mathrm{j}^{\text {th }}$ environment.

$\mathrm{I}_{\mathrm{j}}=$ The environmental index for $\mathrm{j}^{\text {th }}$ environment. 
The analysis of variance for stability parameters the significance of different estimates tested by ' $\mathrm{F}$ ' test:

\section{Mean difference}

$\mathrm{F}=\mathrm{MS}_{1} / \mathrm{MS}_{4}$ (When the pooled deviation is significant)

$\mathrm{F}=\mathrm{MS}_{1} / \mathrm{MS}_{5}$ (When the pooled deviation is non-significant)

$\mathrm{G} \times \mathrm{E}$ interaction

$$
\mathrm{F}=\mathrm{MS}_{2} / \mathrm{MS}_{5}
$$

\section{G x E (linear)}

$\mathrm{F}=\mathrm{MS}_{3} / \mathrm{MS}_{4}$ (When the pooled deviation is significant)

$\mathrm{F}=\mathrm{MS}_{3} / \mathrm{MS}_{5}$ (When the pooled deviation is non-significant)

\section{Estimation of stability parameters}

Two parameters of stability viz. regression coefficient $\left(b_{i}\right)$ and mean square deviation from linear regression $\left(S^{2} d_{i}\right)$ were calculated. The regression coefficient $\left(b_{i}\right)$ is the regression of the performance of each genotype under different environments on the environmental index. It was estimated as:

$$
b_{i}=\frac{\sum_{j=1}^{s} Y_{i j} \times I_{j}}{\sum_{j=1}^{s} I_{j}^{2}}
$$

Hypothesis Regression coefficient assumed zero and unity was tested by using ' $t$ ' test

$$
\begin{array}{cc}
\mathrm{H}_{0}: \mathrm{b}=0^{t_{[n-2]}}=\frac{\frac{b}{S E b}}{S E-1} \\
\mathrm{H}_{0}: \mathrm{b}=1^{t_{[n-2]}}=\sqrt{\frac{b-1}{S E b}} \\
S E_{b i}=\sqrt{\left.\left[\left(\delta_{i}^{2} /\{(s-2)) \sum_{j=1}^{s} I_{j}^{2}\right)\right\}\right]}
\end{array}
$$

Where,
Estimation deviation from regression $\left(\mathrm{S}^{2} \mathrm{~d}_{\mathrm{i}}\right)$ for each genotype was calculated as follow:

$$
S_{d i}^{2}=\frac{d_{i}^{D}}{s-2}-\frac{M S E}{r^{2}}
$$

Significance of $\mathrm{S}^{2} \mathrm{~d}_{\mathrm{i}}$ was tested as follows:

$$
F_{[1, s-2]}=\left[\frac{a_{1}^{R}}{s-2}\right] /\left[\frac{N S E}{r}\right]
$$

Where,

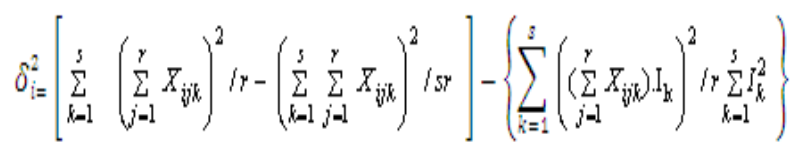

$\mathrm{I}_{\mathrm{k}}=$ Environmental index for $\mathrm{k}^{\text {th }}$ environment i.e.

$$
\sum_{i=1}^{g} \sum_{k=1}^{r} X_{i j} / r g-\left(\sum_{k=1}^{s} \sum_{i=1}^{g} \sum_{j=1}^{r} X_{i j k}\right) / s g r
$$

$X_{i j k}=$ Value of $\mathrm{i}^{\text {th }}$ genotypes in $\mathrm{j}^{\text {th }}$ replication of $\mathrm{k}^{\text {th }}$ environments.

$\mathrm{r}$ and $\mathrm{s}=$ Number of replications and environments, respectively

MSE $=$ Pooled error mean square

\section{Results and Discussion}

\section{Stability analysis}

The stability of the genotypes was estimated using the Eberhart and Russell (1966) model. Analysis of variance for phenotypic stability was carried out only for plant height and ear head length as error variance was homogeneous in different environments for these two traits only. Analysis of variance (Table 1) revealed significant mean square for genotypes, environment linear, G x E linear and pooled deviation for both the characters.

The genotypes had non-significant $S^{2} d_{i}$ along with higher mean values were classified on the basis of $b_{i}$ as $b_{i}<1, b i=1$ and bi $>1$. For plant height a perusal of $S^{2} d_{i}$ revealed that out of 46 genotypes, 22 genotypes, (5 lines, 16 crosses and 1 check) exhibited non- 
significant deviation from regression $\left(\mathrm{S}^{2} \mathrm{~d}_{\mathrm{i}}\right)$. Out of these only L7 x T3 (242.25) was having plant height more than the best check CSV 23 (224.25). Out of 5 lines $\mathrm{L}_{4}$ was having $b_{i}=1$ (1.97) as it significantly deviating from zero but not deviating from unity. In rest of the four lines $b_{i}$ neither deviating from zero nor from unity. Among the crosses $\mathrm{L}_{6} \times \mathrm{T}_{1}$ (1.91) and $\mathrm{L}_{4} \times \mathrm{T}_{2}$ (1.26) were having $\mathrm{b}_{i}=1$ as the $\mathrm{b}_{i}$ were deviating from zero but not from unity. In rest of the 14 hybrids $b_{i}$ neither significantly deviating from zero nor from unity. The similar situation was observed in check CSH 25 also (Table 3). As regards to ear head length a perusal of $S^{2} d_{i}$ revealed that out of 46 genotypes, 29 genotypes, (10 parents, 16 crosses and 3 checks) exhibited non-significant deviation from regression $\left(S^{2} d_{i}\right)$. None of these parents and crosses exhibited mean values more than best check CSH 25 (33.75).

The regression coefficient $b_{i}$ greater than 1 was observed in $\mathrm{L}_{2}$ (2.98) and $\mathrm{L}_{8} \times \mathrm{T}_{2}$ (2.10), $b_{i}=1$ in $\mathrm{T}_{1}(1.84), \mathrm{L}_{4} \times \mathrm{T}_{2}(1.64), \mathrm{L}_{5} \times \mathrm{T}_{1}$ (1.36) and check CSH 25 (1.01). The $b_{i}$ for these genotypes were significantly deviating from zero but not from unity. For rest of the genotypes where $S^{2} d_{i}$ was non significant $b_{i}$ neither deviating from zero nor from unity (Table 3).

For judging buffering ability of genotypes under variable plant populations testing of stability is essential. Genotypes having buffering ability for fluctuation of plant population are most desirable, secondly genotype having predictable behaviour may be recommended for that plant population. In present investigation different plant population were maintained by adopting different spacing and Eberhart and Russell (1966) model was used to estimate the stability and genotypes with high per se performance with non-significant $S^{2}$ di were classified on the basis of regression coefficient $\left(b_{i}\right)$. The genotypes with $b_{i}<1$ (significantly less than 1) were identified for adverse environmental conditions, bi > 1 (significantly higher than 1) for favorable environmental conditions and $b_{i}=1$ for unknown or unpredictable environmental conditions. The error mean square was homogeneous for plant height and ear head length therefore; stability was worked out for these two characters. For plant height 22 genotypes including five lines, one check and 16 crosses having none significant $S^{2} d_{i}$. In these one line $\mathrm{L}_{4}$ and two crosses $\mathrm{L}_{2} \times \mathrm{T}_{1}$ and $\mathrm{L}_{4} \times \mathrm{T}_{2}$ having $\mathrm{b}_{\mathrm{i}}=1$. In rest of the genotypes where $S^{2} d_{i}$ was non-significant bi neither deviating from zero nor from unity. All the three crosses having economic heterosis for grain yield were having significant $S^{2} d_{i}$. For ear head length the $S^{2} d_{i}$ was non-significant in three testers, seven lines, sixteen crosses and three checks.

The regression coefficient $b_{i}>1$ observed in $\mathrm{L}_{2}$ and $\mathrm{L}_{8} \times \mathrm{T}_{2}$ and $\mathrm{b}_{\mathrm{i}}=1$ in $\mathrm{T}_{1}, \mathrm{~L}_{4} \times \mathrm{T}_{2}$ and $\mathrm{L}_{5}$ $\mathrm{x} \mathrm{T}_{1}$ and check CSH 25. For rest of the genotypes where $S^{2} d_{i}$ was non-significant, $b_{i}$ neither deviating neither from zero nor from unity. The cross $L_{1} \times T_{3}$ having economic heterosis for grain yield having nonsignificant $S^{2} d_{i}$ and $b_{i}$. For other two crosses $L_{2} \times T_{3}$ and $L_{6} \times T_{3}$ the $S^{2} d_{i}$ was significant this indicates instability for plant height and ear head length in crosses $\mathrm{L}_{2} \times \mathrm{T}_{3}$ and $\mathrm{L}_{6} \times \mathrm{T}_{3}$ therefore these hybrids may be tested under wider range of environmental condition with more control to reduce the error variance between the environments. Similar results i.e., non significant $S^{2} d_{i}$ and identification of genotypes on the basis of $b_{i}$ for one or more characters were also obtained by Palanisamy and Prasad, (1980), Dangi et al., (1980), Desai and Deore (1980, Singh and Nayeem (1980), Meena et al., (2017) Shahane and Bapat (1981) Patil et al., (1991) and Prabhakar and Patil (2002). 
Table.1 Mean square for plant height and ear head length [Eberhart and Russel, 1966]

\begin{tabular}{|c|c|c|c|c|c|c|c|}
\hline S. No. & Characters & Genotype & $\mathbf{E}+(\mathbf{G} \times \mathbf{E})$ & $\mathbf{E}(\mathbf{L})$ & $\mathbf{G} \times \mathbf{E}(\mathbf{L})$ & Pool dev. & Pool Err \\
\hline & & [45] & [138] & [1] & [45] & [92] & [360] \\
\hline 1 & Plant height & $3802.29 * *$ & $640.00 * *$ & 4.08 & $727.65 * *$ & $604.04 * *$ & 84.82 \\
\hline 2 & Ear head length & $14.30 * *$ & $5.20 * *$ & 0.07 & $7.19 * *$ & $4.29 * *$ & 1.69 \\
\hline
\end{tabular}

*, ** Significant at 5 and 1 percent level of significance

Table.2 Mean square over the environment for plant height and ear head length

\begin{tabular}{|c|c|c|c|c|}
\hline S. No. & Source & df & Plant height & Ear head length \\
\hline 1. & Environment & 3 & $8631.70 * *$ & $148.40 * *$ \\
\hline 2. & Rep./Env & 8 & $894.14 * *$ & $10.80^{*}$ \\
\hline \multirow[t]{12}{*}{3.} & Genotype & 45 & $11407.00 * *$ & $42.91 * *$ \\
\hline & Check & 2 & $7361.40 * *$ & $160.19 * *$ \\
\hline & P vs Chk & 1 & $69417.00 * *$ & $72.93 * *$ \\
\hline & Parent & 12 & $5505.50 * *$ & $51.04 * *$ \\
\hline & Tester & 2 & $13099.00 * *$ & $136.69 * *$ \\
\hline & Line & 9 & $4037.30 * *$ & $35.39 * *$ \\
\hline & $\mathrm{T}$ v/s L & 1 & $3532.60 * *$ & $20.53 * *$ \\
\hline & $\mathrm{P}$ v/s C & 1 & $127000.00 * *$ & $144.26^{* *}$ \\
\hline & Cross & 29 & $9816.50 * *$ & $28.74 * *$ \\
\hline & Tester & 2 & $98585.00 * *$ & $60.43 * *$ \\
\hline & Line & 9 & $3819.90 * *$ & $45.46^{* *}$ \\
\hline & $\mathrm{L} \times \mathrm{T}$ & 18 & $2951.70 * *$ & $16.87 * *$ \\
\hline \multirow[t]{12}{*}{4.} & $G \times E$ & 135 & $1770.90 * *$ & $12.66^{* *} *$ \\
\hline & Check x E & 6 & $1880.80 * *$ & 6.27 \\
\hline & Chk Vs P x E & 3 & $1454.10 * *$ & 6.79 \\
\hline & $P \times E$ & 36 & $1697.10 * *$ & $11.20 * *$ \\
\hline & $\mathrm{T} \times \mathrm{E}$ & 6 & $574.45^{*}$ & 4.88 \\
\hline & $\mathrm{L} \times \mathrm{E}$ & 27 & $1443.50 * *$ & $12.75 * *$ \\
\hline & $\mathrm{T} v / \mathrm{s} \mathrm{L} \times \mathrm{E}$ & 3 & $6225.00 * *$ & 9.82 \\
\hline & $\mathrm{P}$ v/s C x E & 3 & $668.12 *$ & 1.27 \\
\hline & Cross x E & 87 & $1855.60 * *$ & $14.27 * *$ \\
\hline & $\mathrm{T} \times \mathrm{E}$ & 6 & $1047.20 * *$ & $23.60 * *$ \\
\hline & $\mathrm{LxE}$ & 27 & $2067.90 * *$ & $14.72 * *$ \\
\hline & $\mathrm{L} \times \mathrm{T} \times \mathrm{E}$ & 54 & $1839.30 * *$ & $13.01 * *$ \\
\hline 5. & Pooled Error & 360 & 254.47 & 5.07 \\
\hline
\end{tabular}

$*$, ** Significant at 5 and 1 percent level of significance 
Table.3 Stability parameters for plant height and ear head length

\begin{tabular}{|c|c|c|c|c|c|c|c|}
\hline \multirow{2}{*}{ S. No. } & \multirow{2}{*}{ Genotype } & \multicolumn{3}{|c|}{ Plant height (cm) } & \multicolumn{3}{|c|}{ Ear head length $(\mathrm{cm})$} \\
\hline & & $\boldsymbol{\mu}_{\mathrm{i}}$ & $\mathbf{b}_{\mathbf{i}}$ & $S^{2} d_{i}$ & $\mu_{i}$ & $\mathbf{b}_{\mathbf{i}}$ & $\mathbf{S}^{2} \mathbf{d}_{\mathrm{i}}$ \\
\hline 1 & $\mathrm{~T} 1$ & 139.50 & -0.97 & $510.862 * *$ & 25.67 & $1.84^{*}$ & -1.461 \\
\hline 2 & $\mathrm{~T} 2$ & 157.92 & 0.75 & $853.106^{* *}$ & 32.33 & 2.81 & 1.253 \\
\hline 3 & T3 & 203.67 & 0.82 & $237.840^{*}$ & 28.08 & 0.78 & -1.516 \\
\hline 4 & L1 & 145.00 & 3.24 & $2553.194 * *$ & 28.42 & 1.92 & 2.847 \\
\hline 5 & $\mathrm{~L} 2$ & 161.50 & 1.23 & 24.794 & 31.67 & $2.98 *+$ & -1.043 \\
\hline 6 & L3 & 143.08 & 0.61 & -34.102 & 28.08 & 0.29 & -1.009 \\
\hline 7 & L4 & 127.67 & $1.97 *$ & -58.299 & 25.25 & -0.07 & $7.010 * *$ \\
\hline 8 & L5 & 152.17 & 0.38 & $272.884 *$ & 28.17 & 2.19 & 2.388 \\
\hline 9 & L6 & 154.17 & -0.01 & -24.221 & 28.17 & 0.56 & 1.183 \\
\hline 10 & L7 & 193.00 & 2.31 & $1370.194 * *$ & 26.00 & 0.13 & 0.395 \\
\hline 11 & L8 & 177.42 & 2.93 & $1813.476 * *$ & 28.25 & 1.00 & 0.502 \\
\hline 12 & L9 & 155.17 & 1.87 & $252.644^{*}$ & 26.92 & 0.04 & $3.570^{*}$ \\
\hline 13 & L10 & 148.17 & 1.16 & -41.386 & 27.42 & -0.67 & $4.959 *$ \\
\hline 14 & L1 x T1 & 152.17 & -0.64 & -38.625 & 26.08 & 0.77 & 0.384 \\
\hline 15 & L2 $\times$ T1 & 188.58 & 2.20 & $2019.305^{* * *}$ & 30.08 & 4.12 & $5.698^{*}$ \\
\hline 16 & L3 x T1 & 182.08 & 1.08 & $1285.494 * *$ & 26.58 & 0.88 & $11.219 * *$ \\
\hline 17 & L4 x T1 & 189.42 & -1.79 & $776.279 * *$ & 29.25 & 2.58 & $5.698 *$ \\
\hline 18 & L5 x T1 & 203.83 & 0.37 & 144.481 & 31.42 & $1.36^{*}$ & -1.542 \\
\hline 19 & L6 x T1 & 187.58 & $1.91^{*}$ & -69.062 & 29.33 & 1.40 & $9.275^{* *}$ \\
\hline 20 & L7 x T1 & 180.08 & -0.10 & -69.694 & 29.67 & 1.55 & -0.807 \\
\hline 21 & L8 x T1 & 168.25 & -0.29 & -49.598 & 28.75 & 0.72 & 1.176 \\
\hline 22 & L9 x T1 & 168.50 & 1.62 & 26.777 & 28.33 & 1.10 & 3.130 \\
\hline 23 & $\mathrm{~L} 10 \times \mathrm{T} 1$ & 207.67 & 1.36 & $1567.323 * *$ & 27.67 & 0.71 & 0.380 \\
\hline 24 & L1 x T2 & 150.50 & 0.28 & 17.608 & 30.17 & 1.22 & -1.385 \\
\hline 25 & $\mathrm{~L} 2 \times \mathrm{T} 2$ & 171.92 & 1.63 & 74.839 & 31.25 & 1.95 & 0.561 \\
\hline 26 & $\mathrm{~L} 3 \times \mathrm{T} 2$ & 160.50 & 3.07 & $449.861 * *$ & 30.33 & -1.51 & $7.867 * *$ \\
\hline 27 & $\mathrm{~L} 4 \times \mathrm{T} 2$ & 141.75 & $1.26 * *$ & -81.965 & 29.08 & $1.64^{*}$ & -1.568 \\
\hline 28 & L5 $x$ T2 & 200.50 & -0.20 & $376.324 * *$ & 30.00 & 2.12 & $3.870^{*}$ \\
\hline 29 & L6 $\times$ T2 & 179.58 & 1.66 & 41.428 & 29.58 & 2.03 & $6.037 *$ \\
\hline 30 & $\mathrm{~L} 7 \times \mathrm{T} 2$ & 173.50 & -0.61 & 66.230 & 32.08 & -1.74 & $3.782 *$ \\
\hline 31 & L8 $\times$ T2 & 177.42 & -0.80 & 17.294 & 31.58 & $2.10 * *+$ & -1.558 \\
\hline 32 & L9 $x$ T2 & 175.58 & -2.13 & 100.751 & 27.92 & 0.44 & $8.152^{* *}$ \\
\hline 33 & $\mathrm{~L} 10 \times \mathrm{T} 2$ & 168.08 & 2.44 & 29.223 & 28.00 & 0.66 & $7.058^{* *}$ \\
\hline 34 & L1 x T3 & 224.67 & -1.41 & $557.547 * *$ & 30.08 & 0.14 & -0.571 \\
\hline 35 & $\mathrm{~L} 2 \times \mathrm{T} 3$ & 217.25 & 3.29 & $723.488^{* *}$ & 29.17 & 0.74 & $6.809 * *$ \\
\hline 36 & L3 $x$ T3 & 251.00 & 4.01 & $217.570^{*}$ & 29.50 & 0.69 & $7.033^{* * *}$ \\
\hline 37 & L4 x T3 & 223.17 & -0.19 & $1636.850 * *$ & 28.17 & 1.22 & 2.411 \\
\hline 38 & L5 $x$ T3 & 222.50 & 5.56 & $777.227 * *$ & 29.42 & 0.55 & -0.352 \\
\hline 39 & L6 x T3 & 230.58 & 1.93 & $1397.485 * *$ & 29.33 & 0.33 & -0.426 \\
\hline 40 & L7 $x$ T3 & 242.25 & 3.21 & 56.159 & 30.33 & 1.26 & $13.427 * *$ \\
\hline 41 & L8 $\times$ T3 & 229.17 & 0.03 & $486.347 * *$ & 29.42 & 0.90 & 0.032 \\
\hline 42 & L9 x T3 & 190.17 & 1.45 & -35.793 & 25.75 & 0.52 & -1.313 \\
\hline 43 & L10 x T3 & 216.75 & -3.04 & $1881.016^{* *}$ & 27.17 & 0.97 & $7.064 * *$ \\
\hline 44 & CSV 23 & 224.25 & 2.27 & $386.981 * *$ & 28.25 & 0.62 & -1.276 \\
\hline 45 & CSV 27 & 218.25 & -0.46 & $1425.628 * *$ & 26.83 & -0.89 & 1.638 \\
\hline 46 & CSH 25 & 178.67 & 0.70 & -41.740 & 33.75 & $1.01 *$ & -1.620 \\
\hline
\end{tabular}

*, ** Significant at 5 and 1 percent level of significance

+ Significant deviation of $b$ from unity at 5 percent level of significance 
Two crosses $\mathrm{L}_{2} \times \mathrm{T}_{3}$ and $\mathrm{L}_{6} \times \mathrm{T}_{3}$ having economic heterosis more than 15 per cent for grain yield and dry fodder yield, good SCA, involving one good GCA parents, nicking in flowering in normal spacing environment and male parent taller than the female parent are identified to contribute in the coordinated trials for multilocation testing. If perform well these crosses will serve the purpose of dual purpose sorghum. Apart from above, cross $L_{1}$ $\mathrm{X} \mathrm{T}_{3}$ is also identified for contribution in coordinated trials for grain purposes as it has very high economic heterosis for grain yield $(56.65 \%)$ in medium spacing environment i.e. $30 \times 10 \mathrm{~cm}$ along with good nicking in flowering and taller male parent. Selection may also be exercised for transgressive segregants in segregating generations of ICSA $29003 \mathrm{~B} \times \mathrm{SPV} 1822$ as this cross having high heterosis, good SCA and involving both good general combiner parents.

\section{Acknowledgments}

Authers are highly thankful to ICAR (Indian Council of Agricultural Research) for granting study leave for $\mathrm{Ph}$. D degree, to MPUAT (Maharana Pratap University of Agriculture and Technology) Rajasthan College of Agriculture, Udaipur Rajasthan for their support for this study, to ICRISAT (International Crops Research Institute for the Semi-Arid Tropics) and to IIMR (Indian Institute of Millets Research, Hyderabad) for granting CMS Lines (A\&B).

\section{References}

Anonymous 2015. FAOSTAT, Food and Agriculture Organization of the United Nations Statistics Division, Rome.

Bahadure DM, Marker S, Umakanth AV, Prabhakar, Ramteke PW, Patil JV and Rana BS (2015) Combining ability and heterosis on millable stalk and sugar concentration for bioethanol production across environments in sweet sorghum (Sorghum bicolor (L.) Moench). Electronic Journal of Plant Breeding 6: 58-65.

Bhadouriya, N. S. and Saxena, M. K. (1997). Combining ability studies in sorghum through diallel analysis. Crop Res., 14(2): 253-256.

Bunphan D, Jaisil P, Sanitchon J, Knoll JE and Anderson WF (2015) Heterosis and combining ability of F1 hybrid sweet sorghum in Thailand. Crop Science 55: 178-187.

Daljit Singh. 1979. Diallel analysis for combining ability over environments. Indian J. Genet., 39(3): 383-386.

Bhavsar, V. V. and Borikar, S. T. (2002). Combining ability studies in sorghum involving diverse cytosteriles. J. Maharashtra Agric. Univ., 27(1): 35-38.

Chaudhary, S.B., Patil, J.V., Thombare, B.B. and Kulkarni, V.M. (2004). Selection of parents based on combining ability in sorghum [Sorghum bicolor L. Moench]. Annals of Plant Physiology 20 (1): 9597.

Doggett H, 1988. Sorghum. Longman Scientific \& Technical, London. Cereal Sci 44: 236-251

Fisher, R. A. (1932). The Genetical Theory of Natural Selection. Clarendon, Oxford.

Griffing, B. (1956). Concept of general and specific combining ability in relation to diallel crossing system. Aust. J. Biol. Sci., 9: 463-493.

Iyanar, K., Gopalan, A. and Ramasamy, P. (2001). Combining ability analysis in sorghum [Sorghum bicolor (L.) Moench]. Annals of Agriculture Research New Series, 22 (3): 341-345. Indhubala M, Ganesamurthy K and Punitha D (2010) Combining ability studies for quality traits in Sweet Sorghum (Sorghum bicolor (L.) Moench). The Madras Agricultural Journal 97: 17-20.

Karale, M. U, Suryavanshi, Y. B. and Mehtre, 
S. S. (1998). Combining ability studies in sorghum (Sorghum bicolor (L.) Moench). Andhra Agric. J., 45: 42-46.

Kaul, S. L., Rafiq, F. M. and Singh, K. (2003). Heterobeltiosis and combining ability for grain yield components in post rainy season sorghum. International Sorghum and Millets News Letter, 44: 21-23.

Leonilo V. Gramaje. Joanne D. Caguiat. John Oscar S. Enriquez. Quirino D. dela Cruz. Reneth A. Millas. Jake E. Carampatana. Dindo Agustin A. Tabanao. (2020). Heterosis and combining ability analysis in CMS hybrid rice. Euphytica 216:14.

Mara Jane da Rocha1, José Airton Rodrigues Nunes, Rafael Augusto da Costa Parrella, Pakizza Sherma da Silva Leite, Gabrielle Maria Romeiro Lombardi, Mayra Luiza Costa Moura, Robert Eugene Schaffert and Adriano Teodoro Bruzi (2018). General and specific combining ability in sweet sorghum. Crop Breeding and Applied Biotechnology, 18:365-372.

Meena B.L., B.R. Ranwah, S.P. Das, S.K. Meena, R. Kumari, Rumana Khan, V.K. Bhagasara and A. Gangarani Devi (2017). Estimation of Heterosis, Heterobeltiosis and Economic Heterosis in Dual Purpose Sorghum [Sorghum bicolor (L.) Moench]. Int.J.Curr.Microbiol.App.Sci. 6(5): 9901014.

Meena B.L., Ranwah, B.R., Das S.P., Meena H S, Meena, S.K., Kumari R. and Nath, Anamika (2018). Assessment of Economic Heterosis in Dual Purpose Sorghum [Sorghum bicolor (L.)
Moench]. Int.J. Curr.Microbiol. App.Sci 7(7):3196-3205.

Pillai, M.A., Rangaswamy, P., Nadarjan, N., Vannirajan, $\mathrm{C}$ and Ramalingam, J. (1995). Combining ability analysis for ear head characters in sorghum. Indian Journal of Agricultural Research, 29 (2): 98-102.

Patel, S. D.; Patel, A. I.; Patel, R. H.; Mali, S. C.; Patel, V. S. and Kshirsagar, R.M. (2006). Study of heterosis in sorghum. Crop Prot. Prod.,2(2): 59-63.

Rafiq, S. M.; Thete, R. Y.; Madhusudhana, R. and Umakanth, A. V. (2002). Combining ability studies for grain yield and its components in post rainy season where sorghum grown in medium deep and shallow soils. International Sorghum and Millet News Letter,43: 33-37.

Ravindrababu, Y.; Pathak, A. R. and Tank, C. J. (2001). Studies on combining ability for yield and yield attributes in sorghum (Sorghum bicolor (L.) Moench). Crop Res., 22 (2): 274-277.

Salunke, C. B. and Deore, G. N. (2000). Combining ability studies for physiological traits, harvest index and grain yield in rabi sorghum. Ann. Plant Physiol., 14 (2): 190-195.

Thakare, D.P., Ghorade, R. B and Bagade A.B. (2014). Combining ability studies in Grain Sorghum using line $\mathrm{X}$ tester analysis. Int.J. Curr.Microbiol. App.Sci 3(10) 594-603.

Yadav, R .and Pahuja, S.K. (2007). Combining ability for fodder yield and its components in forage sorghum. Forage Research, 32 (4): 220-223.

\section{How to cite this article:}

Meena, B. L., B. R. Ranwah, H. S. Meena, M. D. Meena, K. N. Meena and Rai. P. K. 2020. Stability Analysis in Dual Purpose Sorghum [Sorghum bicolor (L.) Moench]. Int.J.Curr.Microbiol.App.Sci. 9(03): 2521-2530. doi: https://doi.org/10.20546/ijcmas.2020.903.289 